\title{
Ethanol and cocaine increases microtubule stability and decreases [11C]MPC-6827 uptake in SH-SY5Y cells
}

\section{Naresh Damuka}

Wake Forest University School of Medicine

Miranda E Orr

Wake Forest University School of Medicine

Paul W Czoty

Wake Forest University School of Medicine

Jeffrey L Weiner

Wake Forest University School of Medicine

Thomas J Martin

Wake Forest University School of Medicine

Michael A Nader

Wake Forest University School of Medicine

Avinash $\mathrm{H}$ Bansode

Wake Forest University School of Medicine

Buddhika S Liyana Pathirannahel

Wake Forest University School of Medicine

Akiva Mintz

Columbia University Medical Center: Columbia University Irving Medical Center

Shannon L Macauley

Wake Forest University School of Medicine

Suzanne Craft

Wake Forest University School of Medicine

Kiran Kumar Solingapuram Sai ( $\square$ ksolinga@wakehealth.edu )

Wake Forest University School of Medicine

\section{Short Report}

Keywords: Microtubule, cytoskeleton, substance use disorder, in vitro binding, biomarkers

Posted Date: February 17th, 2021

DOl: https://doi.org/10.21203/rs.3.rs-205196/v1 
License: (c) (i) This work is licensed under a Creative Commons Attribution 4.0 International License. Read Full License

Version of Record: A version of this preprint was published at Molecular Biology Reports on April 20th, 2021. See the published version at https://doi.org/10.1007/s11033-021-06336-7. 


\section{Abstract}

Microtubules (MTs) are structural units in the cytoskeleton. In brain cells they are responsible for axonal transport, information processing, and signaling mechanisms. Proper function of these processes is critical for healthy brain functions. Alcohol and substance use disorders (AUD/SUDs) affects the function and organization of MTs in the brain, making them a potential neuroimaging marker to study the resulting impairment of overall neurobehavioral and cognitive processes. Our lab reported the first brainpenetrant MT-tracking Positron Emission Tomography (PET) ligand $\left[{ }^{11} \mathrm{C}\right] \mathrm{MPC}-6827$ and demonstrated its in vivo utility in rodents and non-human primates. To further explore the in vivo imaging potential of $\left[{ }^{11} \mathrm{C}\right] \mathrm{MPC}-6827$, we need to investigate its mechanism of action. Here, we report preliminary in vitro binding results in SH-SY5Y neuroblastoma cells exposed to ethanol (EtOH) or cocaine in combination with multiple agents that alter MT stability. EtOH and cocaine treatments increased MT stability and decreased free tubulin monomers. Our initial cell-binding assay demonstrated that $\left[{ }^{11} \mathrm{C}\right] \mathrm{MPC}-6827$ selectively bound to free/unbound tubulin units. Consistent with this mechanism of action, we observed lower $\left[{ }^{11} \mathrm{C}\right] \mathrm{MPC}-6827$ uptake in SH-SY5Y cells after EtOH and cocaine treatments (e.g., fewer free tubulin monomers). We are currently performing in vivo PET imaging and ex vivo biodistribution studies in rodent and nonhuman primate models of AUD and SUDs.

\section{Background}

Cytoskeletal defects, including alterations in microtubule stability, axonal transport and actin dynamics, have been characterized in several psychiatric and neurodegenerative disorders, including alcohol and substance use disorders (AUD/SUDs) and Alzheimer's disease, suggesting they are a common feature contributing to neurodegeneration. An organized neuronal cytoskeleton is required for nervous system development, maintenance, and regenerative processes after injury. Its three components intermediate filaments, actin filaments, and microtubules (MTs), all play a vital role in neurological processes. MTs are critical to cellular structure; as neuronal backbones they facilitate cell division, axonal transport, and neurotransmission. MTs are hetero-dimer units formed from $\alpha$ - and $\beta$-tubulin monomers.[1] Essential biophysical functions, including cellular signaling and axoplasmic transport, depend on the structural integrity of MTs i.e., polymerization with bound and free tubulin units and MT integrity is heavily dysregulated in AUD and SUDs.[2-5] Addictive behaviors lead to many adaptations in postsynaptic spine structure that result in profound alterations in synaptic transmission.[6] At the molecular level, synaptic activity triggers diverse signaling pathways, which, in turn regulate and reorganize cytoskeletonassociated proteins. For example, repeated cocaine administration has been shown to change stathmin, a regulatory protein crucial to MT dynamics, $[7,6]$ causing morphologic changes.[8]

Neuronal structural changes may contribute to the progression of AUD and SUDs.[9] Chronic ethanol (EtOH) exposure significantly stabilizes neuronal and acetylated MTs in hepatic PC12 cells,[10] increases dendrite lengths and neurite outgrowth and causes aberrant sprouting of hippocampal neurites.[11] Loss of $a$ and $\beta$ free tubulin units in the caudate nucleus, cortex, and cerebellum was noted in post-mortem 
brain samples from individuals diagnosed with AUD. Repeated exposure to drugs of abuse like alcohol and cocaine induces structural plasticity $[12,13]$ in many brain circuits and changes in the density and morphology of dendritic spines. $[5,14,15]$ These alterations have significant consequences including cognitive deficits and neurodegeneration.[16,17] Prolonged SUD is also associated with brain injury characterized by impaired synaptogenesis, cellular migration, and neurogenesis-all of which require proper MT functioning.[18] [19] MT agents (MTAs), believed to work primarily by altering MT network integrity, are widely being investigated as drug candidates to treat cancer, brain disorders, and cardiovascular diseases. Thus, MT integrity is important to many neurochemical pathways commonly associated with SUD. However, studies of cytoskeleton-dependent structural plasticity resulting from alcohol and cocaine use have focused predominantly on actin and filament dynamics; molecular level MT impairments remains largely unexplored. Positron Emission Tomography (PET) imaging is a sensitive modality to examine and quantify in vivo MT-based changes in the neurochemical cascades of SUD.

MPC-6827 is a small molecule MTA that causes mitotic arrest and cell death. It exerts antitumor (glioblastoma) properties by binding to $\beta$-tubulin sites. We reported the automated radiochemical synthesis of $\left[{ }^{11} \mathrm{C}\right] \mathrm{MPC}-6827$ as the first brain-penetrating, MT-tracking PET ligand and imaged it in vivo in normal rodents and non-human primates.[20] [21] To establish the potential of $\left[{ }^{11} \mathrm{C}\right] \mathrm{MPC}-6827$ as a PET imaging ligand for various neurological disorders, we need to investigate its mechanism of action. Here, we report our preliminary in vitro evaluations of $\left[{ }^{11} \mathrm{C}\right] \mathrm{MPC}-6827$ in SH-SY5Y neuroblastoma cells[22-24] with (a) two different abused drugs (alcohol and cocaine), and (b) various MT stabilizing and destabilizing agents.

\section{Methods}

To investigate the effects of cocaine and alcohol on tubulin dynamics, we performed a MT-based assay (Cytoskeleton, Inc., Denver, CO, USA)[25-27] in SH-SY5Y neuroblastoma cells treated with $100 \mathrm{mM}$ $\mathrm{EtOH}[10]$ and $1 \mathrm{mM}$ cocaine[8] ( $\mathrm{n}=6 /$ group) for 3 days. This commercially available kit separates large complexes of polymerized MTs attached to nuclei and Golgi bodies into bound and non-polymerized free tubulins. After differential centrifugation, the high-speed pellet supernatant and low-speed pellet samples were isolated and used for western blot analysis. An enhanced Chemiluminescence kit was used to visualize the tubulin bands,[12,11] (Fig. 1a and 2a). Bound/stabilized MT content was significantly higher and unbound/free $\alpha / \beta$ MTs lower in EtOH-treated cells than control cells treated with PBS. Cells treated with cocaine showed no significant difference in bound MTs and slightly fewer free $\alpha / \beta$ MTs than untreated cells possibly due to the accrued rate of MT polymerization with substances. Therefore, both $\mathrm{EtOH}$ and cocaine compromise MT integrity i.e., increase in bound and decrease in free tubulin units. Having demonstrated these drug-induced changes in MT integrity in SH-SY5Y cells, we next aimed to determine whether $\left[{ }^{11} \mathrm{C}\right] \mathrm{MPC}-6827$ could also detect similar MT alterations using the same cells.

We performed cell binding assays in vitro in SH-SY5Y cells with [ $\left.{ }^{11} \mathrm{C}\right] \mathrm{MPC}-6827$ following our previously published protocols.[28-30] The cells were treated with $100 \mathrm{mM} \mathrm{EtOH}$ or $1 \mathrm{mM}$ cocaine[8] ( $\mathrm{n}=6 /$ group) 
for 3 days. We then measured radiotracer binding by adding $\left[{ }^{11} \mathrm{C}\right] \mathrm{MPC}-6827(1-2 \mu \mathrm{Ci} /$ well $)$ and incubating the cells for $5,30,60$, and 90 min at room temperature ( $n=6 /$ time point). To demonstrate tracer specificity, a subgroup of cells $(n=3)$ was pre-treated with non-radioactive MPC-6827 $(1.0 \mu \mathrm{M})$, adding radiotracer $60 \mathrm{~min}$ later and incubating for $30 \mathrm{~min}$. To demonstrate tracer sensitivity to length of drug exposure, cells were treated with $100 \mathrm{mM} \mathrm{EtOH}$ or $1 \mathrm{mM}$ cocaine for $1 \mathrm{~h}, 1$ day, or 3 days and incubated with $\left[{ }^{11} \mathrm{C}\right] \mathrm{MPC}-6827$ for $30 \mathrm{~min}$ at room temperature. All the cells were then washed with PBS and lysed with $1 \mathrm{~N} \mathrm{NaOH}$. Finally, the lysate from each well was g-counted (PerkinElmer, Waltham, MA, USA) and counts-per-minute (cpm) values were normalized to the amount of radioactivity added to each well. Cpm values were then matched with the protein concentration per well, and the data expressed as $\% \mathrm{ID} / \mathrm{mg}$ of protein present in each well.

EtOH- (Fig 1b) and cocaine-treated (Fig 2b) cells demonstrated an 30 $( \pm 2)$ and $\sim 24( \pm 6)$ percent decrease respectively in radioactive uptake versus non-treated controls over the 30-90 min incubation times. Additionally, uptake in EtOH-treated and cocaine-treated cells increased 13( \pm 3$)$ and $\sim 12( \pm 2)$ percent from 5 to 30 min of incubation times respectively and decreased $\sim 53( \pm 2)$ and $\sim 19( \pm 3)$ percent by $90 \mathrm{~min}$ in $\mathrm{EtOH}$ - and cocaine-treated cells; thus demonstrating favorable pharmacokinetics. For the self-blocking assays (Fig 1b), uptake was 78( \pm 1) percent lower after addition of nonradioactive MPC-6827, demonstrating high specificity. Radioactive uptake was decreased $\sim 21( \pm 1)$ and $28( \pm 1)$ percent from $1 \mathrm{~h}$ to 3 days EtOH and cocaine exposures (Fig 3) respectively. Therefore, $\left[{ }^{11} \mathrm{C}\right] \mathrm{MPC}-6827$ uptake decreased selectively with increased exposure to EtOH or cocaine. Moreover, since no significant decrease in radioactivity was observed after 3 days of drug exposure we used the same 3 days exposure in all our assays. MPC-6827 primarily targets the $\beta$ tubulin site at pharmacological doses.[31-33] The lowered radioactive uptake in EtOH- and cocaine-treated SH-SY5Y cells indicates that $\left[{ }^{11} \mathrm{C}\right] \mathrm{MPC}-6827$ uptake correlate well with observed bound/free tubulin changes and may be tracking free $\beta$ tubulin units, as both substance treatments decreased free tubulin content in the same cells.

MTAs are categorized as either stabilizing agents (paclitaxel, laulimalide, and EpoD),[34-36] which favor polymerization of tubulin units and inhibit cell proliferation, or destabilizing agents (vinblastine and mertasine),[37-40] which increase free/unbound tubulins and promote apoptotic cell death. To distinguish their effect on MT integrity in SH-SY5Y cells, we performed the same tubulin-based western blot assays on paclitaxel- and vinblastine-treated cells.[41] The paclitaxel-treated cells had more bound/stabilized MTs, and vinblastine-treated cells had more unbound/free MTs than the untreated cells (Fig 4a). To confirm the free tubulin-based binding mechanism of $\left[{ }^{11} \mathrm{C}\right] \mathrm{MPC}-6827, \mathrm{SH}-\mathrm{SY} 5 Y$ cells were pretreated with different MTAs at $1.0 \mu \mathrm{M}$ concentration, $3.0 \mathrm{~h}$ prior to addiction of $\left[{ }^{11} \mathrm{C}\right] \mathrm{MPC}-6827$. Paclitaxel, laulimalide and EpoD decreased radioactive uptake by $\sim 58( \pm 3), \sim 40( \pm 4)$, and $\sim 66( \pm 7)$ percent respectively, while vinblastine, and mertasine increased it by $\sim 77( \pm 6)$, and $64( \pm 5)$ percent respectively (Fig 4b), confirming that $\left[{ }^{11} \mathrm{C}\right] \mathrm{MPC}-6827$ primarily targets primarily free tubulin units.

\section{Results}


Results of the preliminary $\left[{ }^{11} \mathrm{C}\right] \mathrm{MPC}-6827$ in vitro assays with $\mathrm{EtOH}$ and cocaine treatments at different incubation times in SH-SY5Y cells indicate that radioactive uptake decreases with increased drug exposure. Tests with various MTAs demonstrate that $\left[{ }^{11} \mathrm{C}\right] \mathrm{MPC}-6827$ preferentially binds to free/unbound tubulin units with high selectivity. The radioactive uptake results are well-corroborated with observed changes in bound and free tubulin expressions in SH-SY5Y cells with EtOH and cocaine treatments. Taken together, these studies confirm that $\left[{ }^{11} \mathrm{C}\right] \mathrm{MPC}-6827$ has great potential as an MT imaging agent for defining MT-based mechanisms that underlie the development of alcohol and cocaine addiction. We are currently characterizing its complete in vivo and ex vivo imaging properties in both rodent and nonhuman primate models of AUD/SUDs.

Sources: Cocaine hydrochloride and other reagents were purchased from Sigma Aldrich; MPC 6827 hydrochloride was purchased from Tocris a biotech brand; SH-SY5Y cells was purchased from ATCC (American Type Culture Collection) and the precursor for $\left[{ }^{11} \mathrm{C}\right] \mathrm{MPC}-6827$ was purchased from ABX Inc supplies.

\section{References}

1. Brunden KR, Lee VMY, Smith AB, Trojanowski JQ, Ballatore C (2017) Altered microtubule dynamics in neurodegenerative disease: Therapeutic potential of microtubule-stabilizing drugs. Neurobiology of Disease 105:328-335. doi:https://doi.org/10.1016/j.nbd.2016.12.021

2. Kovalevich J, Cornec A-S, Yao Y, James M, Crowe A, Lee VM-Y, Trojanowski JQ, Smith AB, Ballatore C, Brunden KR (2016) Characterization of Brain-Penetrant Pyrimidine-Containing Molecules with Differential Microtubule-Stabilizing Activities Developed as Potential Therapeutic Agents for Alzheimer's Disease and Related Tauopathies. Journal of Pharmacology and Experimental Therapeutics 357 (2):432-450. doi:10.1124/jpet.115.231175

3. Smith KJ, Butler TR, Prendergast MA (2013) Ethanol impairs microtubule formation via interactions at a microtubule associated protein-sensitive site. Alcohol 47 (7):539-543.

doi:10.1016/j.alcohol.2013.08.001

4. Yan S-cB, Hwang S, Rustan TD, Frey WH (1985) Human brain tubulin purification: Decrease in soluble tubulin with age. Neurochemical Research 10 (1):1-18. doi:10.1007/bf00964768

5. Koob GF (2021) Drug Addiction: Hyperkatifeia/Negative Reinforcement as a Framework for Medications Development. Pharmacological Reviews 73 (1):163-201. doi:10.1124/pharmrev.120.000083

6. Calipari ES, Godino A, Salery M, Damez-Werno DM, Cahill ME, Werner CT, Gancarz AM, Peck EG, Jlayer Z, Rabkin J, Landry JA, Smith ACW, Defilippi P, Kenny PJ, Hurd YL, Neve RL, Dietz DM, Nestler EJ (2019) Synaptic Microtubule-Associated Protein EB3 and SRC Phosphorylation Mediate Structural and Behavioral Adaptations During Withdrawal From Cocaine Self-Administration. The Journal of Neuroscience 39 (29):5634-5646. doi:10.1523/jneurosci.0024-19.2019 
7. Duncan JE, Lytle NK, Zuniga A, Goldstein LSB (2013) The Microtubule Regulatory Protein Stathmin Is Required to Maintain the Integrity of Axonal Microtubules in Drosophila. PLOS ONE 8 (6):e68324. doi:10.1371/journal.pone.0068324

8. Badisa RB, Wi S, Jones Z, Mazzio E, Zhou Y, Rosenberg JT, Latinwo LM, Grant SC, Goodman CB (2018) Cellular and molecular responses to acute cocaine treatment in neuronal-like N2a cells: potential mechanism for its resistance in cell death. Cell Death Discov 4:13. doi:10.1038/s41420018-0078-x

9. Preedy VR (2016) Neuropathology of Drug Addictions and Substance Misuse Volume 1: Foundations of Understanding, Tobacco, Alcohol, Cannabinoids and Opioids. Academic Press,

10. Reiter-Funk CK, Dohrman DP (2005) Chronic ethanol exposure increases microtubule content in PC12 cells. BMC Neurosci 6:16. doi:10.1186/1471-2202-6-16

11. Romero AM, Esteban-Pretel G, Marín MP, Ponsoda X, Ballestín R, Canales JJ, Renau-Piqueras J (2010) Chronic ethanol exposure alters the levels, assembly, and cellular organization of the actin cytoskeleton and microtubules in hippocampal neurons in primary culture. Toxicol Sci 118 (2):602612. doi:10.1093/toxsci/kfq260

12. Reiter-Funk CK, Dohrman DP (2005) Chronic ethanol exposure increases microtubule content in PC12 cells. BMC Neurosci 6:16-16. doi:10.1186/1471-2202-6-16

13. SPINA MG, GRECKSCH G, KOVAR K-A, WOLF G, PUTZKE J (2000) Microtubule-associated Protein 2 (MAP2) and c-fos Expression in the Rat Prefrontal Cortex following Subchronic Treatment with Substituted Amphetamines. Annals of the New York Academy of Sciences 914 (1):65-70. doi:doi:10.1111/j.1749-6632.2000.tb05184.x

14. Koob GF, Volkow ND (2016) Neurobiology of addiction: a neurocircuitry analysis. Lancet Psychiatry 3 (8):760-773. doi:10.1016/s2215-0366(16)00104-8

15. Koob GF (2013) Theoretical frameworks and mechanistic aspects of alcohol addiction: alcohol addiction as a reward deficit disorder. Curr Top Behav Neurosci 13:3-30. doi:10.1007/7854_2011_129

16. Crews FT, Nixon K (2009) Mechanisms of neurodegeneration and regeneration in alcoholism. Alcohol Alcohol 44 (2):115-127. doi:10.1093/alcalc/agn079

17. Crews FT (2008) Alcohol-related neurodegeneration and recovery: mechanisms from animal models. Alcohol research \& health : the journal of the National Institute on Alcohol Abuse and Alcoholism 31 (4):377-388

18. Smith KJ, Butler TR, Prendergast MA (2013) Ethanol impairs microtubule formation via interactions at a microtubule associated protein-sensitive site. Alcohol 47 (7):539-543. doi:https://doi.org/10.1016/j.alcohol.2013.08.001

19. Eira J, Silva CS, Sousa MM, Liz MA (2016) The cytoskeleton as a novel therapeutic target for old neurodegenerative disorders. Progress in Neurobiology 141:61-82. doi:https://doi.org/10.1016/j.pneurobio.2016.04.007

20. Kumar JSD, Solingapuram Sai KK, Prabhakaran J, Oufkir HR, Ramanathan G, Whitlow CT, Dileep H, Mintz A, Mann JJ (2018) Radiosynthesis and in Vivo Evaluation of [11C]MPC-6827, the First Brain 
Penetrant Microtubule PET Ligand. Journal of Medicinal Chemistry 61 (5):2118-2123. doi:10.1021/acs.jmedchem.8b00028

21. Damuka N, Czoty PW, Davis AT, Nader MA, Nader SH, Craft S, Macauley SL, Galbo LK, Epperly PM, Whitlow CT, Davenport AT, Martin TJ, Daunais JB, Mintz A, Sai KKS (2020) PET Imaging of [(11)C]MPC-6827, a Microtubule-Based Radiotracer in Non-Human Primate Brains. Molecules 25 (10). doi:10.3390/molecules25102289

22. Balasooriya IS, Wimalasena K (2007) Are SH-SY5Y and MN9D cell lines truly dopaminergic?

23. Tian P, Shi W, Liu J, Wang J, Ma C, Qi Q, Cong B, Li Y (2015) Expression of the $\mu$, K, and $\delta$-opioid receptors and tyrosine hydroxylase in MN9D cells. Int J Clin Exp Pathol 8 (5):4863-4868

24. Biedler JL, Roffler-Tarlov S, Schachner M, Freedman LS (1978) Multiple neurotransmitter synthesis by human neuroblastoma cell lines and clones. Cancer Res 38 (11 Pt 1):3751-3757

25. Romero AM, Esteban-Pretel G, Marín MP, Ponsoda X, Ballestín R, Canales JJ, Renau-Piqueras JJTS (2010) Chronic ethanol exposure alters the levels, assembly, and cellular organization of the actin cytoskeleton and microtubules in hippocampal neurons in primary culture. 118 (2):602-612

26. Zhang G, Liu X, Li J, Ledet E, Alvarez X, Qi Y, Fu X, Sartor O, Dong Y, Zhang HJO (2015) Androgen receptor splice variants circumvent AR blockade by microtubule-targeting agents. 6 (27):23358

27. Reiter-Funk CK, Dohrman DPJBn (2005) Chronic ethanol exposure increases microtubule content in PC12 cells. $6(1): 16$

28. Sai KKS, Sattiraju A, Almaguel FG, Xuan A, Rideout S, Krishnaswamy RS, Zhang J, Herpai DM, Debinski W, Mintz A (2017) Peptide-based PET imaging of the tumor restricted IL13RA2 biomarker. Oncotarget 8 (31):50997-51007. doi:10.18632/oncotarget.16549

29. Solingapuram Sai KK, Das BC, Sattiraju A, Almaguel FG, Craft S, Mintz A (2017) Radiolabeling and initial biological evaluation of [(18)F]KBM-1 for imaging RAR-a receptors in neuroblastoma. Bioorganic \& medicinal chemistry letters 27 (6):1425-1427. doi:10.1016/j.bmcl.2017.01.093

30. Sattiraju A, Solingapuram Sai KK, Xuan A, Pandya DN, Almaguel FG, Wadas TJ, Herpai DM, Debinski W, Mintz A (2017) IL13RA2 targeted alpha particle therapy against glioblastomas. Oncotarget 8 (26):42997-43007. doi:10.18632/oncotarget.17792

31. Kasibhatla S, Baichwal V, Cai SX, Roth B, Skvortsova I, Skvortsov S, Lukas P, English NM, Sirisoma N, Drewe J, Pervin A, Tseng B, Carlson RO, Pleiman CM (2007) MPC-6827: A Small-Molecule Inhibitor of Microtubule Formation That Is Not a Substrate for Multidrug Resistance Pumps. Cancer Research 67 (12):5865-5871. doi:10.1158/0008-5472.Can-07-0127

32. Banerjee S, Hwang D-J, Li W, Miller DD (2016) Current Advances of Tubulin Inhibitors in Nanoparticle Drug Delivery and Vascular Disruption/Angiogenesis. Molecules (Basel, Switzerland) 21 (11):1468. doi:10.3390/molecules21111468

33. Yan W, Yang T, Yang J, Wang T, Yu Y, Wang Y, Chen Q, Bai P, Li D, Ye H, Qiu Q, Zhou Y, Hu Y, Yang S, Wei Y, Li W, Chen L (2018) SKLB060 Reversibly Binds to Colchicine Site of Tubulin and Possesses Efficacy in Multidrug-Resistant Cell Lines. Cellular Physiology and Biochemistry 47 (2):489-504. doi:10.1159/000489983 
34. Zhang B, Carroll J, Trojanowski JQ, Yao Y, Iba M, Potuzak JS, Hogan A-ML, Xie SX, Ballatore C, Smith AB, Lee VM-Y, Brunden KR (2012) The Microtubule-Stabilizing Agent, Epothilone D, Reduces Axonal Dysfunction, Neurotoxicity, Cognitive Deficits, and Alzheimer-Like Pathology in an Interventional Study with Aged Tau Transgenic Mice. The Journal of Neuroscience 32 (11):3601-3611. doi:10.1523/jneurosci.4922-11.2012

35. Prota AE, Bargsten K, Zurwerra D, Field JJ, Díaz JF, Altmann KH, Steinmetz MO (2013) Molecular mechanism of action of microtubule-stabilizing anticancer agents. Science 339 (6119):587-590. doi:10.1126/science.1230582

36. Mooberry SL, Randall-Hlubek DA, Leal RM, Hegde SG, Hubbard RD, Zhang L, Wender PA (2004) Microtubule-stabilizing agents based on designed laulimalide analogues. Proceedings of the National Academy of Sciences of the United States of America 101 (23):8803-8808. doi:10.1073/pnas.0402759101

37. Gigant B, Cormier A, Dorléans A, Ravelli RB, Knossow M (2009) Microtubule-destabilizing agents: structural and mechanistic insights from the interaction of colchicine and vinblastine with tubulin. Top Curr Chem 286:259-278. doi:10.1007/128_2008_11

38. Gigant B, Wang C, Ravelli RB, Roussi F, Steinmetz MO, Curmi PA, Sobel A, Knossow M (2005) Structural basis for the regulation of tubulin by vinblastine. Nature 435 (7041):519-522. doi:10.1038/nature03566

39. Kumar JSD, Prabhakaran J, Damuka N, Hines JW, Kridel SJ, Mann JJ, Mintz A, Solingapuram Sai KK (2020) EVALUATION OF [11C]MPC-6827 AS A MICROTUBULE TARGETING PET RADIOTRACER IN CANCER CELL LINES. International Journal of Pharmacy and Pharmaceutical Sciences 12 (1):43-47. doi:10.22159/ijpps.2020v12i1.35657

40. Adams SR, Yang HC, Savariar EN, Aguilera J, Crisp JL, Jones KA, Whitney MA, Lippman SM, Cohen EE, Tsien RY, Advani SJ (2016) Anti-tubulin drugs conjugated to anti-ErbB antibodies selectively radiosensitize. Nat Commun 7:13019. doi:10.1038/ncomms13019

41. Zhang G, Liu X, Li J, Ledet E, Alvarez X, Qi Y, Fu X, Sartor O, Dong Y, Zhang H (2015) Androgen receptor splice variants circumvent AR blockade by microtubule-targeting agents. Oncotarget 6 (27):23358-23371. doi:10.18632/oncotarget.4396

\section{Figures}




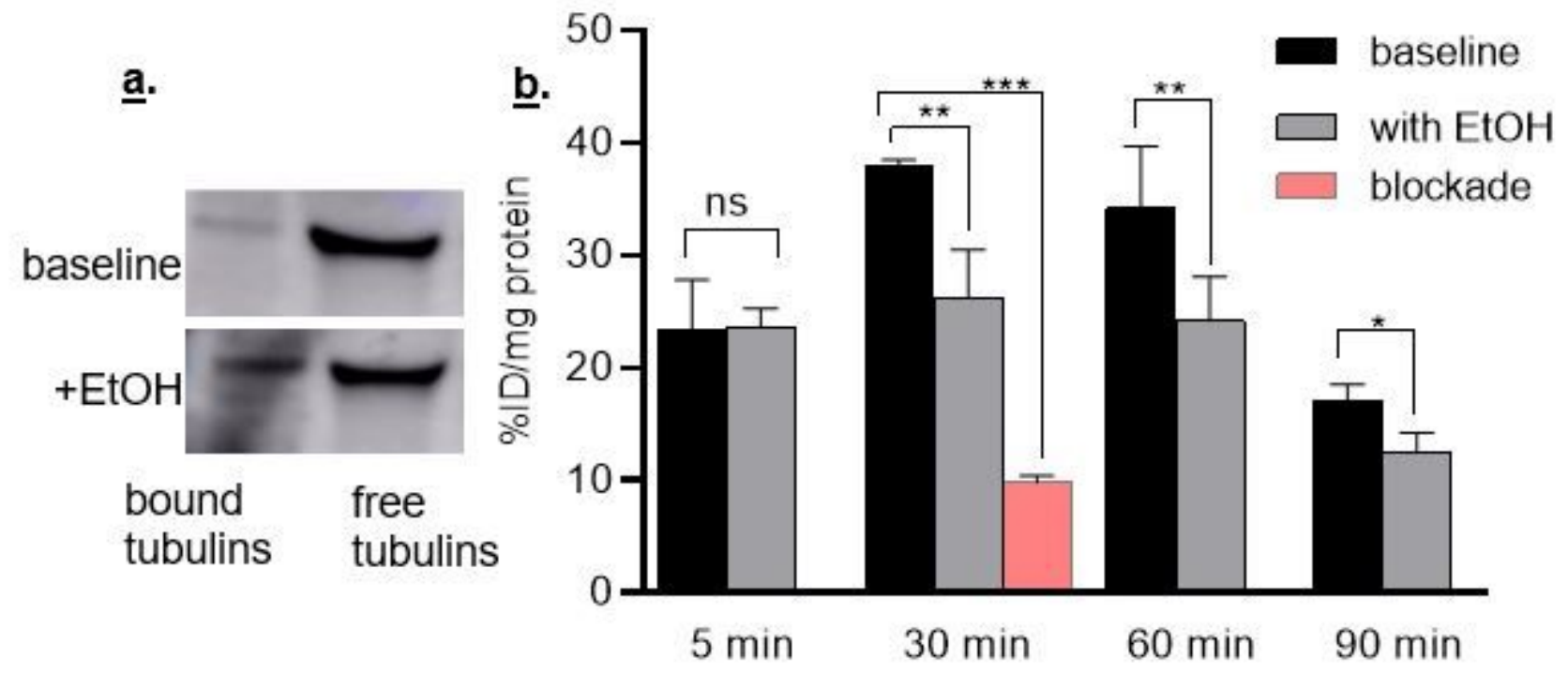

Figure 1

Representative bound and free tubulin a. western blots and b. [11C]MPC-6827 uptake in vitro at different incubation times in SH-SY5Y cells with $\mathrm{EtOH}$ (100 mM/3 days) and without $\mathrm{EtOH}$ treatment ( $\mathrm{n}=6 /$ group); ${ }^{*} \mathrm{p}<0.05$ and ns: non-significant

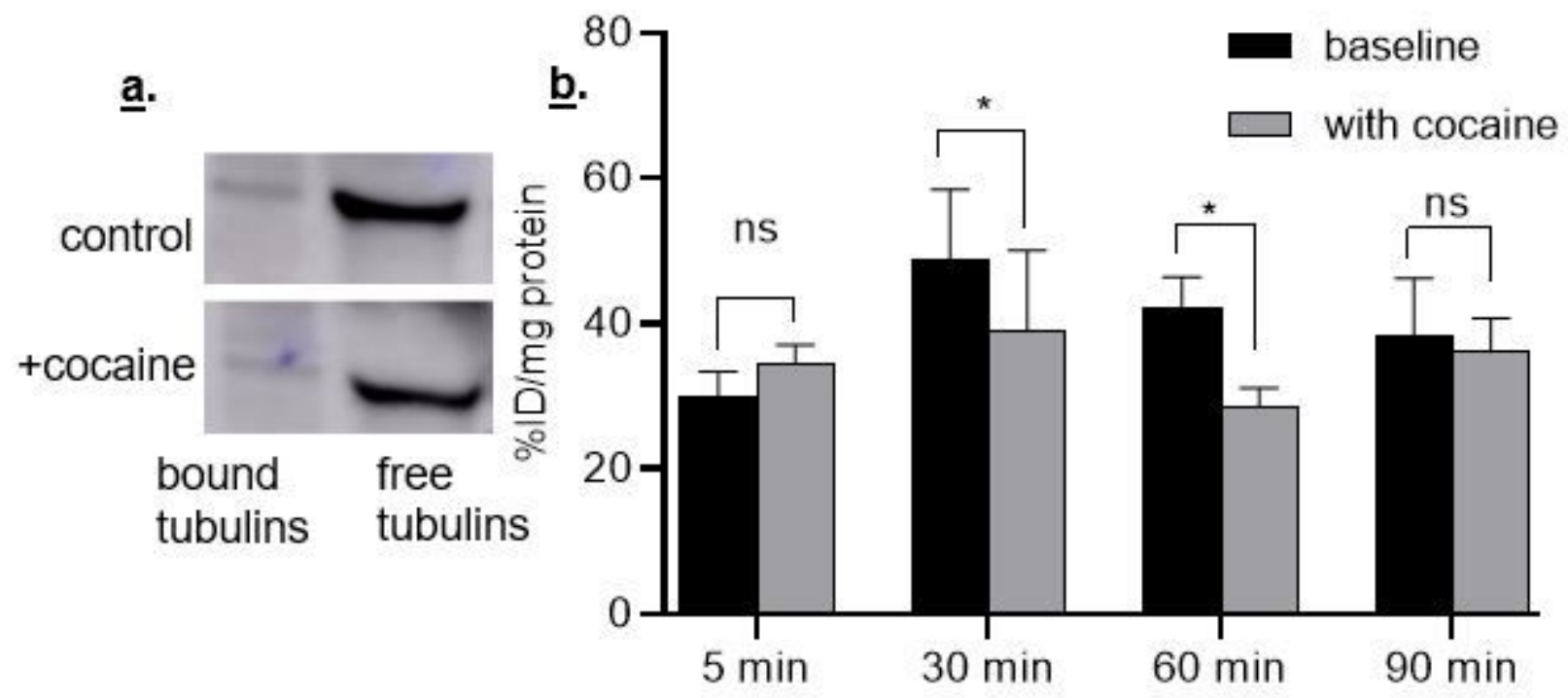

Figure 2

Representative bound and free MT a. western blots and b. [11C]MPC-6827 uptake in vitro at different incubation times in SH-SY5Y cells with cocaine ( $1 \mathrm{mM} / 3$ days) and without cocaine treatment $(n=6)$; ${ }^{*} \mathrm{p}<0.05$ and $\mathrm{ns}$ : non-significant 


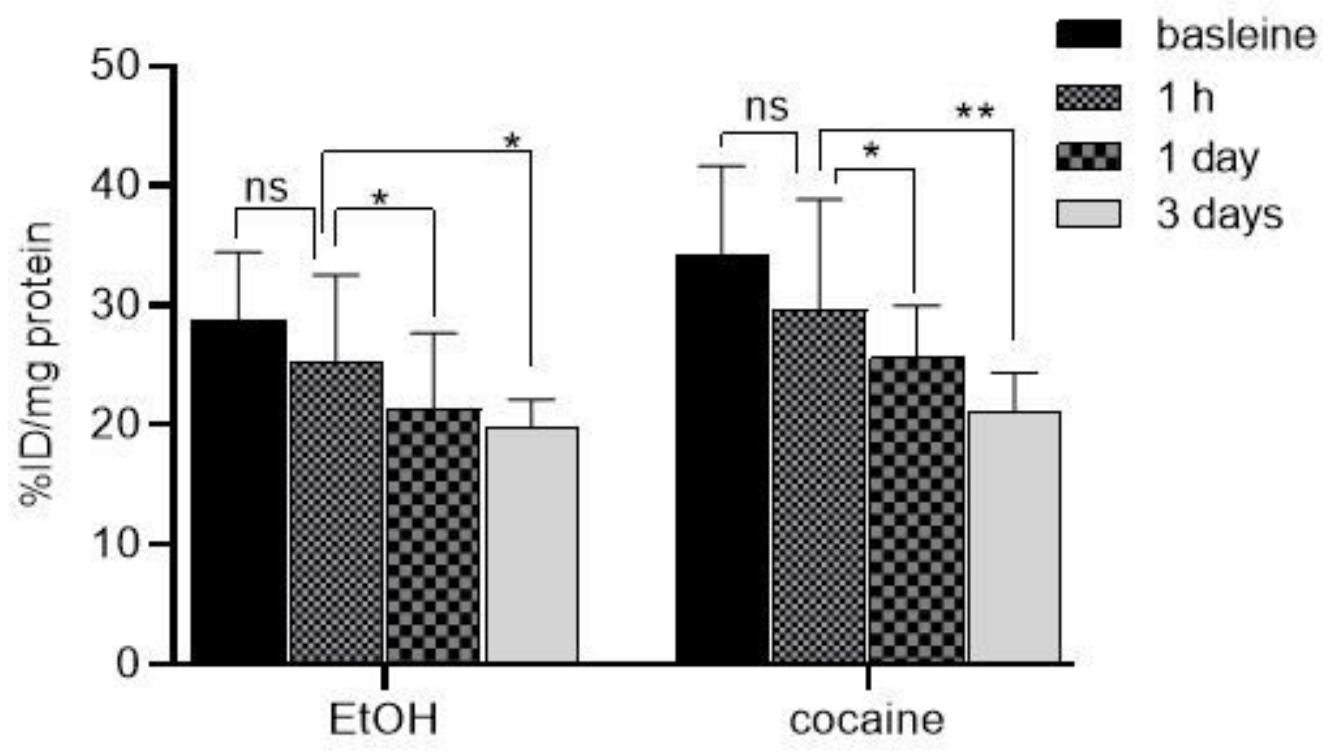

Figure 3

[11C]MPC-6827 uptake in vitro with EtOH $(100 \mathrm{mM})$ and cocaine $(1 \mathrm{mM})$ for $1 \mathrm{~h}, 1$ day and 3 day exposures in SH-SY5Y cells $(n=6)$; ${ }^{\star} p<0.05$ and $n s$ : non-significant

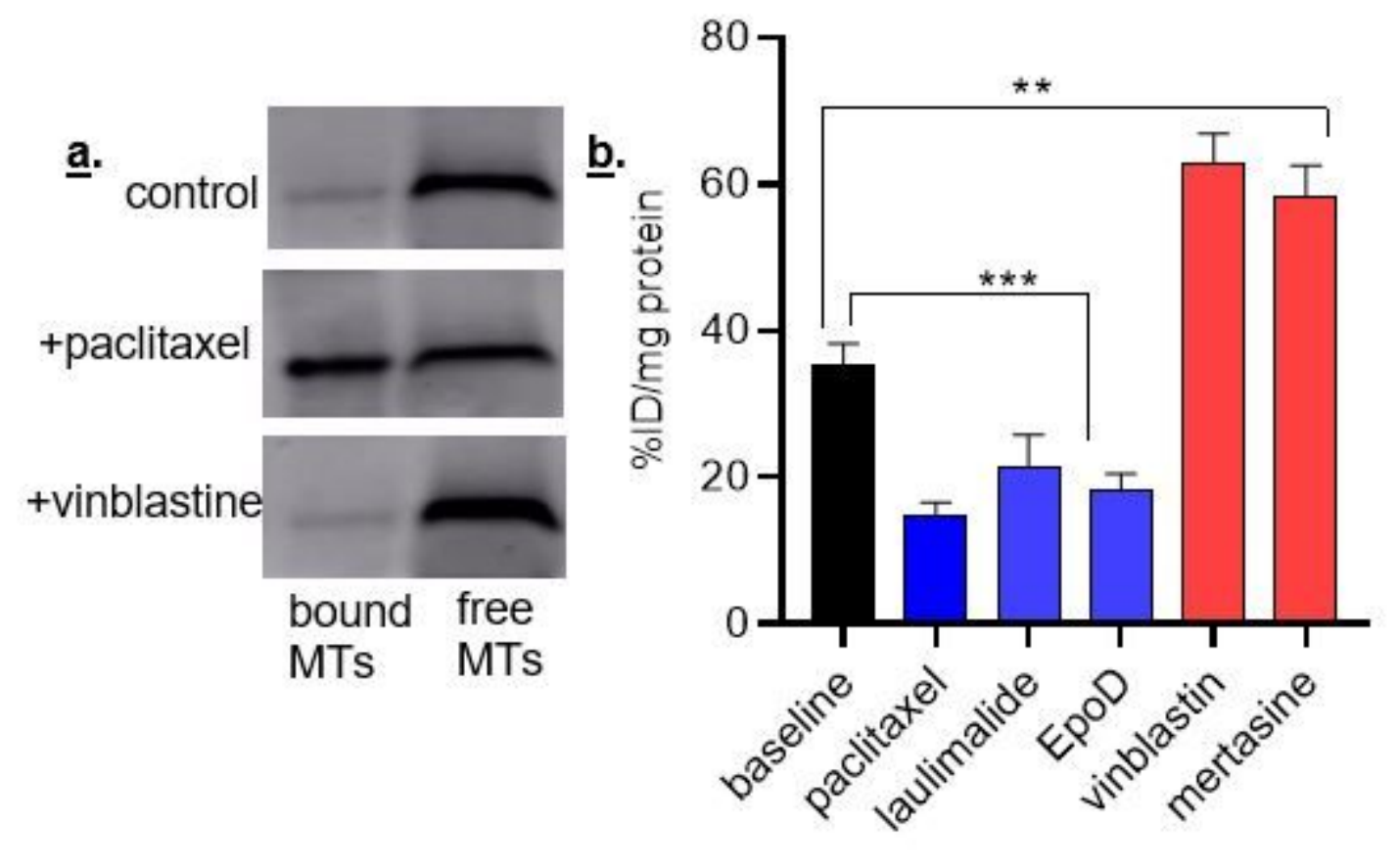

\section{Figure 4}

Representative bound and free tubulin a. western blots and b. [11C]MPC-6827 uptake in vitro with different MT agents $(1 \mu \mathrm{M} / 60 \mathrm{~min})$ in SH-SY5Y cells $(n=6) ;{ }^{*}<0.05$ 